\author{
A. E. HOUSMAN \\ A REASSESSMENT
}


Also by Alan W. Holden

\title{
MOLLY HOLDEN
}

Selected Poems (with a Memoir of Molly Holden)

\author{
Also by J. Roy Birch \\ UNKIND TO UNICORNS \\ Selected Comic Verse of A. E. Housman
}




\title{
A. E. Housman
}

A Reassessment

\author{
Edited by
}

Alan W. Holden

and

J. Roy Birch

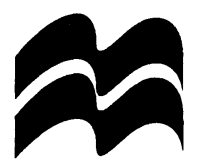


Houndmills, Basingstoke, Hampshire RG21 6XS and London

Companies and representatives throughout the world

A catalogue record for this book is available from the British Library.

ISBN 978-0-333-65803-1

First published in the United States of America 2000 by

ST. MARTIN'S PRESS, INC.,

Scholarly and Reference Division,

175 Fifth Avenue, New York, N.Y. 10010

ISBN 978-1-349-62281-8 ISBN 978-1-349-62279-5 (eBook)

DOI $10.1007 / 978-1-349-62279-5$

Library of Congress Cataloging-in-Publication Data

A.E. Housman : a reassessment / edited by Alan W. Holden and J. Roy

Birch.

p. $\mathrm{cm}$.

Includes bibliographical references and index.

1. Housman, A. E. (Alfred Edward), 1859-1936-Criticism and

interpretation. I. Holden, Alan W., 1926- . II. Birch, J. Roy.

PR4809.H15A849 1999

$821^{\prime} .912-\mathrm{dc} 21 \quad 99-12180$

CIP

Selection, editorial matter and Introduction (C) Alan W. Holden and J. Roy Birch 2000

Text (C) Macmillan Press Ltd 2000

Softcover reprint of the hardcover 1st edition 2000 978-0-312-22318-2

All rights reserved. No reproduction, copy or transmission of this publication may be made without written permission.

No paragraph of this publication may be reproduced, copied or transmitted save with written permission or in accordance with the provisions of the Copyright, Designs and Patents Act 1988, or under the terms of any licence permitting limited copying issued by the Copyright Licensing Agency, 90 Tottenham Court Road, London W1P 0LP.

Any person who does any unauthorised act in relation to this publication may be liable to criminal prosecution and civil claims for damages.

The authors have asserted their rights to be identified as the authors of this work in accordance with the Copyright, Designs and Patents Act 1988.

This book is printed on paper suitable for recycling and made from fully managed and sustained forest sources.

$\begin{array}{lllllllll}10 & 9 & 8 & 7 & 6 & 5 & 4 & 3 & 2\end{array}$

$\begin{array}{llllllllll}09 & 08 & 07 & 06 & 05 & 04 & 03 & 02 & 01 & 00\end{array}$ 


\section{Contents}

Acknowledgements vii

Notes on the Contributors ix

Introduction xiii

1 A. E. Housman's 'Level Tones'

Archie Burnett 1

2 The Critical Reception of A Shropshire Lad

Benjamin F. Fisher 20

3 The Land of Lost Content

Keith Jebb 37

4 Tacit Pledges

Geoffrey Hill 53

5 'Ashes under Uricon': Historicizing A. E. Housman, Reifying T. H. Huxley, Embracing Lucretius

Kenneth Womack 76

6 A. E. Housman and Thomas Hardy

Norman Page

7 'Flowers to Fair': A Shropshire Lad's Legacy of Song Trevor Hold

8 Housman's Manilius

G. P. Goold

9 Lewis Carroll in Shropshire John Bayley

10 The First Edition of A Shropshire Lad in Bookshop and Auction Room

P. G. Naiditch

11 A. E. Housman's Use of Biblical Narrative

Carol Efrati

12 The Spirit of Haiku and A. E. Housman Takeshi Obata

Select Bibliography 



\section{Acknowledgements}

Grateful acknowledgements for copyright permissions in the UK are due to:

- the Society of Authors as the literary representative of the Estate of A. E. Housman;

- Random House UK Limited for the use of the poem 'A worm fed on the heart of Corinth', by Isaac Rosenberg (from The Collected Poems of Isaac Rosenberg, eds Bottomley and Harding, Chatto \& Windus, 1937, re-issued 1979, ed. I. Parsons);

- the poem 'A. E. H.' (Copyright (C) 1979 Kingsley Amis) is reprinted by kind permission of Jonathan Clowes Ltd, London, on behalf of the Kingsley Amis Literary Estate.

For copyright permission in the USA:

- From: THE COLlECTED POEMS OF A. E. HOUSMAN by A. E. Housman, Copyright 1939, 1940, (C) 1965 by Henry Holt and Company, Inc., (C) 1967 by Robert E. Symons. Reprinted by permission of Henry Holt and Company, Inc.

Grateful thanks are also due to Jeremy Crow, at the Society of Authors, for his help and courtesy throughout, and to Charmian Hearne and Julian Honer, at Macmillan, for their help and patience. Many thanks also to Elnora Ferguson for compiling the index, and Cathy Scoffield for typing the text. 



\section{Notes on the Contributors}

John Bayley was Warton Professor of English Literature at Oxford University from 1973 to 1992, and is now Emeritus Professor. His books include The Characters of Love (1960), Tolstoy and the Novel (1966) and Housman's Poems (1992), as well as studies of Shakespeare, Pushkin and Hardy. His novels are In Another Country (1953) and a trilogy, Alice (1994), The Queer Captain (1995), and George's Lair (1996).

Archie Burnett is the editor of the Oxford English Texts volume, The Poems of A. E. Housman (OUP, 1997). It contains all of Housman's verse and a comprehensive textual apparatus and commentary. Previously a Research Fellow of St John's College, Oxford, Dr Burnett teaches English at Oxford Brookes University. He plans a full edition of Housman's correspondence.

Carol Efrati, an American who has resided for many years in Israel, received her doctoral degree from the Hebrew University in Jerusalem for a dissertation on the role of friendship, love and passion in Housman's poetry. Her work on Housman has appeared in Victorian Poetry and she is a regular contributor to the Housman Society Journal. She teaches English composition and literature at the Achva Teachers' College in Jerusalem.

Benjamin F. Fisher, Professor of English at the University of Mississippi, has been bibliographer and American vice-president of the Housman Society for many years. He is an internationally recognized specialist in American and Victorian studies, with particular interests in Poe, the Housmans, the Gothic and bibliographic studies. He serves on the Advisory Boards of Victorian Poetry, English Literature in Transition and Poe Studies. He is currently working on several projects concerning Ella D'Arcy, best known for her connection with The Yellow Book.

George P. Goold retired as Lampson Professor of Latin from Yale University in 1992 and is now Professor Emeritus. He held professional appointments at various universities from 1955, including 
the Chair of Latin at University College, London, 1973-78 (the chair earlier held by Housman). He is General Editor of the Loeb Classical Library. Besides many reviews and articles on Latin and Greek subjects, he has edited and translated Manilius, Catullus, Propertius and Chariton, and is currently revising the Loeb Virgil.

Geoffrey Hill, the distinguished poet, was born in 1938 but a few minutes walk from the birthplace of Housman. Hill attended the County High School in Bromsgrove and Keble College, Oxford, where he is an Honorary Fellow. He has taught at Leeds University and later at Cambridge where he is Honorary Fellow of Emmanuel College. Since 1988 Geoffrey Hill has been a member of the University Professors Programme at Boston University, USA. He is the author of six books of poetry, his latest being Canaan (Penguin, 1997), who also publish Hill's Collected Poems).

Trevor Hold was born in 1939 and studied music at Nottingham University. He has held teaching posts at the Universities of Aberystwyth, Liverpool and Leicester, but now works as a freelance composer, lecturer and writer. His compositions, many of which have been broadcast, include orchestral, choral and chamber music, song cycles and piano music. $\mathrm{He}$ is also a poet and, as well as supplying the libretti for his own song cycles and operas, has published three collections of poetry. He has written on twentieth-century English songwriters, including articles on Warlock and Gurney and a study of Quilter's songs, The Walled-in Garden, which has recently been republished.

Keith Jebb was born in Shropshire. His book A. E. Housman was published in 1992 by Seren Books. A widely published poet and reviewer, he is currently working on the project to revise the complete Oxford English Dictionary.

P. G. Naiditch is the Publications Editor of the Department of Special Collections, and the Classics Bibliographer for the Charles E. Young Research Library, University of California, Los Angeles. He is the author of A. E. Housman at University College, London: the Election of 1892 (1988) and Problems in the Life and Writings of A. E. Housman (1995). He is currently engaged on a reconstruction of Housman's library and a bibliography of his works. 
Takeshi Obata is Professor of the English Literature course at Shirayuri College, Tokyo, and is Chairman of the Housman Society in Japan. He is also one of the Vice-Presidents of the EighteenNineties Society. He is the author of A Study of A. E. Housman and of a Japanese version of The Name and Nature of Poetry, the latter in collaboration with some members of the Housman Society. He has written articles, in various scholarly periodicals, on A. E. Housman, Christina Rossetti, Ernest Dowson, Edward Thomas and Iris Murdoch.

Norman Page is Emeritus Professor of Modern English at the University of Nottingham and Emeritus Professor of English at the University of Alberta. His numerous books on nineteenthcentury and twentieth-century literature include A. E. Housman: A Critical Biography (Macmillan, 1983; reissued 1996). Among his other biographies are Tennyson: an Illustrated Life (1992) and Auden and Isherwood: the Berlin Years (Macmillan, 1998).

Kenneth Womack recently completed his dissertation, The Heavy Industry of the Mind: Ethical Criticism and the Academic Novel, in the Department of English at Northern Illinois University. He works as a Correspondent for the World Shakespeare Bibliography and serves as Associate Editor of the George Eliot-George Henry Lewes Studies. In addition to co-authoring Recent Work in Critical Theory, 1989-1995: an Annotated Bibliography (1996), he has published articles in such journals as the Yearbook of Comparative and General Literature, Biography and The Library Chronicle. He has recently been appointed Assistant Professor of English at Penn State Altoona. 



\section{Introduction}

That the body of work which constitutes A. E. Housman's poetic output is small has often been remarked on. The two books of verse published in his lifetime, A Shropshire Lad and Last Poems, contain 105 poems. Laurence Housman printed 72 after his brother's death in More Poems and Additional Poems. There are also a few translations and the light verse. Moreover, these poems are nearly all short or very short. The longest, 'Hell Gate' (LP $\mathrm{XXXI}$ ), is 104 lines, and the two longest other poems are "Terence, this is stupid stuff' (ASL LXII) at 76 lines and 'The Merry Guide' (ASL XLII) at 60 lines. In the work published in Housman's lifetime, about five-eighths of the poems are 20 lines or fewer in length. And yet this small body of work has aroused intense interest from 1896 to the present day.

The volume edited by Philip Gardner (A. E. Housman: the Critical Heritage, London and New York: Routledge, 1992) is of great value in showing that there was lively and widespread critical attention paid to ASL from the beginning, in both the UK and the USA. The American reviewers were rather more grudging in their response, but, as P. G. Naiditch pointed out in a review of Gardner's book,' there were numerous reviews not reproduced by Gardner, a caveat underlined in some measure by Ben Fisher in the article reproduced in this volume (Chapter 2). Critical interest seems to have outrun general appreciation; it is well known that the first edition (of 500 copies) took about two years to sell out. Grant Richards, who had been much impressed by the book on its appearance and had written a review for the Review of Reviezus, became a publisher shortly after, and took over the publication of $A S L$ for its second and subsequent editions, as well as publishing $L P$ and some of Housman's classical work. The 1898 ASL was also extensively noticed in the press; some of these articles were long and detailed, and, again, were mostly favourable. But even though Richards was an enthusiastic promoter of $A S L$, this second edition (also of 500 copies) sold slowly, so that, by the end of 1902, after two further editions, under 1500 copies had been sold in the UK. From then on, however, the story is of steady 
growth in public appreciation, aided by numerous cheap editions (partly made possible by Housman's refusal, for many years, to take any royalties) and song-settings by many English composers. The 1914-18 war undoubtedly had the effect of increasing the popularity of the poems. It followed naturally that Last Poems would sell in large numbers from the day of publication in 1922. Richards was very cautious in printing only 4000 copies (against Housman's suggestion of 10000 ). By the end of the year (the book was published in October), a further 17000 had been printed.

Again, most reviewers of $L P$, in both the UK and the USA, were high in its praise. Some used the occasion for an extended consideration of Housman's poetry; these writers included J. B. Priestley, H. W. Garrod and J. F. M. MacDonald. Reviews of the posthumous work and the Collected Poems of 1939, as well as of the lecture The Name and Nature of Poetry (1933), were also generally favourable.

It is worth noticing the main thrusts of these commentaries from 1896 on. Many writers believed that the poet was a new voice in the world of the 1890s (one remembers A. E. H.'s protests, when, in later years, an editor wished to include some of the poems from $A S L$ in an anthology of 1890s poetry - on which see Ben Fisher's essay in Chapter 2). A number drew attention to the narrow limits of the poetry, in both style and content, but stressed the consummate skill within these limits. There was considerable reference to the artlessness of the verse (the 'perfect simplicity' of Hubert Bland, the 'sancta simplicitas' of Louise Guiney); but as many critics wrote of the art which conceals art and of a hard-earned surface simplicity (and indeed, this balance between the simple-seeming surface and the linguistic and metric artifice is a feature which may exercise critics in our own day). Local colour ('fresh country pictures', for instance) was sometimes remarked on, or on occasions denied.

Influences or supposed influences upon the poetry were also noted from an early date. The work of Heine was referred to more than once, as were Burns, Robert Louis Stevenson, the ballads, Blake and others, though some reviewers thought the poet in no one else's debt. Rather curiously, for an age much more familiar than our own with the Bible, Housman's biblical allusions do not seem to have aroused much comment from early commentators. 
Gardner, in his long and useful introduction to his Critical Heritage volume, notes that it was not until after Housman's death that 'a significant number of critics began to express dissatisfaction with his work', and P. G. Naiditch, in the article referred to above, refines this, making the point that it was the later critics, such as Raymond Mortimer, Orwell and Lawrence Leighton, who drew specific and unfavourable attention to what they took to be Housman's self-pity and the 'adolescent' qualities of the verse, terms apparently not used by the early critics at all. Cyril Connolly's piece in the New Statesman of May 1936, an obituary, which evoked replies from F. L. Lucas, Martin Cooper, L. P. Wilkinson and John Sparrow, spoke of triteness of technique, banality of thought and the 'metrically morbid experiments in the five-line stanza' (a puzzling phrase, then and now; Connolly was clearly not aware of the quite common use of the five-line stanza, with varying rhyme-schemes, by such Victorian poets as George Meredith, D. G. Rossetti and Arthur Symons). Connolly also loftily dismissed Housman's claim to be a classical poet - a claim, as one of the correspondents pointed out, never made by Housman himself.

Now came the time for the biographers and the writers of memoirs. One of the earliest books was the Bromsgrove Memorial Supplement, Alfred Edward Housman: Recollections, with contributions by, among others, Katharine Symonds, A. E. H.'s sister, Laurence Housman, R. W. Chambers, and A. S. F. Gow. Laurence Housman's A. E. H. (published in the USA as My Brother, A. E. Housman) followed in 1937. This contained a memoir, a number of letters (most of them previously unpublished), poems (the Additional Poems), and light verse and parodies. In quick succession followed $A$ Buried Life by Percy Withers (1940) - Withers had known A. E. H. from 1917 - and, of great importance and entertainment value, Grant Richards's Housman: 1897-1936 (1941). Richards had of course known Housman for a long time and had gradually established a friendship with him (such that they sometimes went on holiday together). His book contained numerous letters. The biographies proper began to appear after the Second World War: George L. Watson's A. E. Housman in 1957, and Maude M. Hawkins's A. E. Housman: Man Behind a Mask and Norman Marlow's A. E. Housman: Scholar and Poet both in 1958.

When Christopher Ricks edited the volume $A$. E. Housman: $a$ Collection of Critical Essays in 1968, he stated in the introduction that 'the quality of Housman's poetry ... is no longer assured of 
recognition'; though even so, he acknowledged that the poems 'disrupt all the normal allegiances', since among Housman's admirers were to be counted William Empson and (represented in the volume) Cleanth Brooks, F. W. Bateson and Randall Jarrell. Hugh Kenner and F. R. Leavis were noted as adverse critics. Ricks printed poems by Auden, Pound and Kingsley Amis to underline the close attention paid to A. E. H. by modern poets.

The essays chosen by Ricks were almost exclusively reprinted from elsewhere. A number offer close readings of particular poems, Randall Jarrell's and Cleanth Brooks's contributions being the most noteworthy in this respect. Brooks, in one of his general comments, makes comparisons with the work of William Faulkner and Ernest Hemingway - courage and stoic endurance are presented for our consideration and approval by all three writers. John Wain sees as a fault what the earlier reviewers of Last Poems saw largely as a virtue, namely that there is no development discernible between 1896 and 1922. There is some attention paid to relationships (or lack of them) between the poetry and the life, and between the scholarship and the poetry. J. P. Sullivan's essay is concerned with defining what he takes to be Housman's limitations as a model for contemporary classical scholarship, and in the only article written especially for the volume, F. W. Bateson stresses (though not in great detail) the importance of considering Housman's sexual orientation in any approach to the poetry.

The years since Ricks's volume have seen a further increase in the amount of attention paid to Housman, as man, poet and classical scholar. The Housman Society was founded in 1973 in Bromsgrove, Housman's birthplace. Its purpose is to foster interest in the Housman family, including Laurence and Clemence, brother and sister of A. E. H., both of them writers and artists, but inevitably most of the material in the Journal (published annually since 1974, except for a gap in 1976) is concerned with A. E. H. Several worthwhile books have been published in the critical, biographical and bibliographical fields: John Pugh's Bromsgrove and the Housmans (1974), Richard Perceval Graves's A. E. Housman (1979), Norman Page's A. E. Housman: a Critical Biography (1983, reprinted 1996), John Bayley's Housman's Poems (1992), Keith Jebb's A. E. Housman (1992), A. E. Housman: a Bibliography (John Carter and John Sparrow, revised edition by William White, 1982) and P. G. Naiditch's Problems in the Life and Writings of A. E. Housman (1995). 
The 1996 celebrations marking the centenary of the publication of A Shropshire Lad, with academic lectures, poetry readings and music, in venues as varied as Ludlow, Oxford, London and Bromsgrove (the list is by no means exhaustive), were well attended and enthusiastically received; the current appeal of Housman is not simply to the scholarly.

The present volume, which was conceived as part of the centenary celebrations, shows that academic interest in A. E. H. is still strong and widespread: contributions from the UK, the USA, Israel and Japan are included. As to the variety of focus, that is clearly apparent. Here are, for instance, close readings, historical and bibliographical studies, and comparisons with other writers - indeed, with another culture. Housman is seen as poet, man, classicist, and source of inspiration for song-writers. Some might challenge Keith Jebb's assertion '[w] hat ASL is about... is not Housman's homosexuality, but the inexpressibility of homosexuality as such, of a homosexual community,' but the challenge would need to explore the linguistic parameters in the close detail evident in his essay. Perhaps a bibliographer with much time at his disposal could take up either - or both - of the challenges offered by Ben Fisher and Paul Naiditch: to present the totality of the initial responses in the press to the publication of $A S L$ (as Professor Fisher remarks, there were, in 1896, 70-odd daily newspapers in London alone), and to determine exactly how many copies of ASL were printed, and sold, by Grant Richards. ${ }^{2}$ Geoffrey Hill, one of the most highly regarded of contemporary poets, has provided us with a challenge to examine the tension in Housman's poetry between form and content and to reconsider whether the simple delight and pleasure commonly held to be derivable from the poetry is so simple. And Carol Efrati's suggestion that it is possible that Housman knew some Hebrew could surely bear some further investigation.

This introduction began with a restatement of the familiar paradox that Housman's poetry, though limited in scale and apparently in scope, has nonetheless evoked much attention since the first publication of ASL. John Bayley confesses that his earlier statement, that 'we always know where we are with Housman', needs considerable qualification: 'his personality is both extremely definite and remarkably evasive' - and, as he and other critics point out, the same simultaneous clarity and evasiveness present one of the most intriguing aspects of the verse, perhaps still to be completely 
assessed. But, equally intriguingly, there are other areas of A. E. H.'s works which have not been fully explored. Housman always had a great interest in metrics; in The Name and Nature of Poetry, he tells us that he had first thought of taking the 'Artifice of Versification' as his subject for the lecture, and claims that he could have added a few useful pages to the 'few pages of Coventry Patmore and a few of Frederic Myers [which] contain all, so far as I know, or all of value, which has been written on such matters' - a coat-trailing assertion when one remembers the audience for the lecture (a footnote mentions some of the topics he might have touched on). But has there been a full treatment of Housman's practices in matters of rhythm, rhyme and verse-form? A re-examination of Housman's Notebooks, now in the Library of Congress, is part of Dr Archie Burnett's complete re-edition of the poems (see Select Bibliography), and will no doubt establish whether, as has been suggested, Tom Burns Haber's book ${ }^{3}$ has quite substantial omissions. Housman's prose has not been fully or adequately discussed, though Norman Page has some excellent paragraphs on the subject. ${ }^{4}$ More peripherally, perhaps, little attention has been paid to the comic verse, or to Housman's influence on other poets.

It is of course of little use to look forward even twenty or thirty years, to try to guess in what ways Housman's poetry will be read, if at all. Perhaps during the next century his wry view of pastoralism will become impossibly remote for the general reader and an exhausted, or pointless, topic for the literary critic (supposing such continue to exist). We cannot know. But then, few reviewers or readers in 1896 could have predicted that the new slim volume, of so little consequence to any publisher that the poet had to pay the costs of publication himself, would remain constantly in print for the next one hundred years.

\section{Notes}

1. Housman Society Journal, vol. 20 (1994) 79-103.

2. As Naiditch writes: '[D]espite sixty years of bibliographical investigation, no one at present knows how many editions and reprints of $A S L$ have appeared; none, how many copies of all these printings were issued. Of copies printed and bound, none can say how many were sold.' 
3. The Manuscript Poems of A. E. Housman (London: OUP, 1955).

4. A. E. Housman: A Critical Biography (London: Macmillan, 1983, repr. 1996) pp. 139-47.

Throughout this volume, the accepted convention for referring to Housman's poems has been generally followed: ASL (for A Shropshive Lad); LP (for Last Poenis); MP (for More Poems); AP (for Additional Poems); CP (Collected Poems). 